\title{
Correction to: Health economic evaluation of an internet intervention for depression (deprexis), a randomized controlled trial
}

\author{
Viola Gräfe ${ }^{1 *}$, Steffen Moritz ${ }^{2}$ and Wolfgang Greiner ${ }^{1}$
}

\author{
Correction to: Health Econ Rev 10, 19 (2020) \\ https://doi.org/10.1186/s13561-020-00273-0
}

Following publication of the original article [1], the authors reported an error in their paper after publication that the supplementary table was captured as Table 3 while Table 3 was used as the supplementary file. In addition the table headings were incorrectly assigned. The correct Table 3 is shown below. The original article [1] has been updated.

\section{Author details}

'Department of Health Economics and Health Care Management, School of Public Health, Bielefeld University, Universitätsstraße 25, 33615 Bielefeld, Germany. ${ }^{2}$ Department of Psychiatry and Psychotherapy, University Medical Center Hamburg-Eppendorf, Martinistraße 52, 20246 Hamburg, Germany.

Published online: 30 July 2020

\section{Reference}

1. Gräfe V, Moritz S, Greiner W. Health economic evaluation of an internet intervention for depression (deprexis), a randomized controlled trial. Health Econ Rev. 2020;10:19 https://doi.org/10.1186/s13561-020-00273-0.

\footnotetext{
The original article can be found online at https://doi.org/10.1186/s13561020-00273-0

* Correspondence: viola.graefe@uni-bielefeld.de

The original article can be found online at https://doi.org/10.1186/s13561020-00273-0

'Department of Health Economics and Health Care Management, School of Public Health, Bielefeld University, Universitätsstraße 25, 33615 Bielefeld, Germany

Full list of author information is available at the end of the article
}

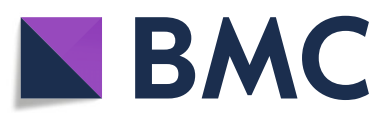

( The Author(s). 2020 Open Access This article is licensed under a Creative Commons Attribution 4.0 International License, which permits use, sharing, adaptation, distribution and reproduction in any medium or format, as long as you give appropriate credit to the original author(s) and the source, provide a link to the Creative Commons licence, and indicate if changes were made. The images or other third party material in this article are included in the article's Creative Commons licence, unless indicated otherwise in a credit line to the material. If material is not included in the article's Creative Commons licence and your intended use is not permitted by statutory regulation or exceeds the permitted use, you will need to obtain permission directly from the copyright holder. To view a copy of this licence, visit http://creativecommons.org/licenses/by/4.0/. The Creative Commons Public Domain Dedication waiver (http://creativecommons.org/publicdomain/zero/1.0/) applies to the data made available in this article, unless otherwise stated in a credit line to the data. 
Table 3 Between-group effect sizes of secondary outcomes

\begin{tabular}{|c|c|c|c|c|c|c|}
\hline & \multicolumn{2}{|c|}{ Post-assessment } & \multicolumn{2}{|c|}{ 3-monts follow-up } & \multicolumn{2}{|c|}{ 9-monts follow-up } \\
\hline & Cohen's d & $95 \%-\mathrm{Cl}$ & Cohen's d & $95 \%-\mathrm{Cl}$ & Cohen's d & $95 \%-\mathrm{Cl}$ \\
\hline PHQ-9 & 0.37 & $0.29-0.44$ & 0.23 & $0.15-0.31$ & 0.15 & $0.07-0.23$ \\
\hline SF-12 physical summary scale & 0.18 & $0.10-0.25$ & 0.09 & $0.01-0.17$ & 0.14 & $0.05-0.22$ \\
\hline SF-12 mental summary scale & 0.33 & $0.25-0.40$ & 0.22 & $0.15-0.30$ & 0.09 & $0.01-0.18$ \\
\hline EQ-5D-3 L & 0.14 & $0.07-0.22$ & 0.10 & $0.02-0.17$ & 0.09 & $0.01-0.18$ \\
\hline WSAS & 0.23 & $0.15-0.31$ & 0.15 & $0.07-0.23$ & 0.12 & $0.02-0.24$ \\
\hline
\end{tabular}

Cohen's $d$ was calculated as the difference between the mean of the intervention and control group, divided by the pooled standard deviation of both groups. The effect sizes are defined as small $(d=0.2)$, medium $(d=0.5)$ and large $(d=0.8)$ 